\title{
Developmental Appearance of Proteins Identified by Two-Dimensional Gel Electrophoresis in Mouse Gonadal Tissue
}

\author{
E.J. DURBIN, ${ }^{1}$ R.P. ERICKSON, ${ }^{1,2}$ M.L. VAN KEUREN, ${ }^{2,3}$ R.A. IACOB, ${ }^{2}$ aND D.M. KURNIT ${ }^{1,2,3}$ \\ Departments of Human Genetics, ${ }^{1}$ Pediatrics and Communicable Diseases, ${ }^{2}$ and the Howard Hughes Medical \\ Institute, ${ }^{3}$ University of Michigan School of Medicine, Ann Arbor, Michigan
}

\begin{abstract}
Gonadal protein patterns of the mouse were studied during fetal development by twodimensional gel electrophoresis. Fetal mice at days 8.5, $10.5,12.5$, and 14.5 post-coitum were analyzed for male or female specific proteins. Although no sex specific proteins were found, several proteins were found which were expressed in significantiy different amounts in the two sexes at about the time of gonadal differentiation. Hence, quantitative differences, rather than qualitative ones, could be related to the initiation of testis or ovary development.
\end{abstract}

Key Words: Gonadal protein, fetal mice, Gonadal differentiation

\section{INTRODUCTION}

Since the cloning of the putative sex-determining gene by Page and co-workers (1987) there has been a great amount of research, the results of which have failed to substantiate the position of the Zinc Finger $Y$ chromosome gene (ZFY) as the testis determining factor (TDF). In mice there are two copies of this sequence on the $\mathrm{Y}$ chromosome and they are designated $Z f y-1$ and $Z f y-2$ (Mardon et al., 1989). Erickson and Verga (1989) presented arguments against ZFY being the sex-determining gene and other authors have reported results that bear this out. For instance, Sinclair et al. (1988) found that sequences homologous to ZFY are located on autosomes in marsupials but not on the $\mathrm{Y}$ chromosome. In addition, the inability to detect transcription of $Z f y-1$ in mouse newborn testes by Mardon and Page (1989) argues against a role for $Z f y-1$ in gonadal development. Kallikin et al. (1989) found post-meiotic expression of $Z f y$ - 1 in adult mouse testis whereas Affara et al. (1989) found evidence for ZFY transcripts in human fetal testis. Others have found $Z f y-1$ to have three transcripts in differentiating fetal mouse testes at about the time one can recognize the testes (Koopman et al., 1989). These authors found that the expression at this time was in germ cells which are not necessary for testes determinations. Therefore, evidence for a role of $Z f y-1$ in sex determination is lacking. More recently, a second candidate sex determining gene (SRY) has been identified (Palmer et al., 1989; Sinclair et al., 1990). Its mouse homologue is expressed in the gonadal ridge at 11.5 days and is a good candidate for a necessary, but perhaps not sufficient (since human males with SRY, but lacking ZFY, are not completely masculinized; Burgoyne, 1989), sex determining gene since a mutation in it leads to $\mathrm{XY}$ females (Gubbay et al., 1990).

The present study was undertaken to determine whether we could detect testis or ovary-specific proteins by two-dimensional gel electrophoresis of proteins synthesized in gonadal ridges in developing mice. We looked at four different time periods including the time of testicular differentiation in mice. Although we found no proteins that were male specific during all four times of development, we did find several proteins that showed developmental patterns with potential for playing a role in testicular differentiation in mice.

\section{MATERIALS AND METHODS}

Day 14.5 post-coitum fetuses of the C57BL/6J strain mice were dissected and sexed using transillumination (Eicher et al., 1982). The gonadal ridges were then incubated in $50 \mu \mathrm{Ci} / \mathrm{ml}^{35} \mathrm{~S}$-methionine $(>800 \mathrm{Ci} / \mathrm{mmol}$; Amersham) in Dulbecco's Minimal Essential Medium (DMEM) minus methionine for 4-5 hours in a $\mathrm{CO}_{2}$ incubator at $37^{\circ} \mathrm{C}$. Protein samples were prepared by the methods of Garrels (1979). The protein samples were heat denatured in the presence of SDS and 2-mercaptoethanol followed by treatment with DNase/ RNase to reduce viscosity. The samples were then snap-frozen in liquid nitrogen and shipped to Protein Databases, Inc. (Huntington Station, NY). There the samples were lyophilized and suspended in $9.5 \mathrm{M}$ Urea, $100 \mathrm{mM}$ DTT plus $2 \%$ NP-40, and carrier ampholines followed by determination of specific activity. Twodimensional electrophoresis was performed according to Garrels (1979) using broad range ampholytes ( $\mathrm{pH} 4.0$ to 7.8 ) in the first dimension and $12.5 \%$ acrylamide gels in the second. The gels were processed for fluorography and multiple autoradiographic exposures were made of each gel. Gel films were scanned with an Eikonix 78/99 camera system at a resolution of approximately $20 \mu \mathrm{M}$ $(1120 \times 1120$ pixels $)$. The images were then processed

Received August 6, 1990; accepted October 18, 1990.

Address reprint requests to Dr. R.P. Erickson, Department of Pediatrics, University of Arizona Health Sciences Center, Tucson, AZ 85724. 
using the PDQUEST computer analysis programs of Garrels et al. (1984). Images were edited to only include well-resolved protein spots. After the films were scanned, merged, and spot detected, the experimental data were assembled into a matchset. The matchset consisted of films of gels from four males and two females.

For the second study, day 8.5 total embryos, day 10.5 trunks, and day 12.5 gonadal ridges were labeled as above and snap-frozen until their sex was determined using placental DNA in a Southern hybridization with probe pM720 (Phillips et al., 1982; provided by Dr. Eva Eicher). One male and one female for each of the three stages was analyzed. For Southern hybridization, DNA was prepared from the placenta of individual fetuses by standard extraction procedures (Maniatis et al., 1982). The DNA was digested with EcoRI, run on a $0.7 \%$ agarose gel, and transferred to Hybond-N (Amersham). The pM720 insert was labeled by random priming (Feinberg and Vogelstein, 1984) using $50 \mu \mathrm{Ci}{ }^{32} \mathrm{P}$. dCTP. Prehybridization was for 16 hours in $1 \mathrm{M} \mathrm{NaCl}$, $1 \%$ SDS at $65^{\circ} \mathrm{C}$. Hybridization was for 16 hours at $65^{\circ} \mathrm{C}$ in $1 \mathrm{M} \mathrm{NaCl}, 1 \% \mathrm{SDS}, 100 \mu \mathrm{g} / \mathrm{ml}$ denatured salmon sperm DNA, and $10^{6} \mathrm{cpm} / \mathrm{ml} \mathrm{M} 720$ probe. After hybridization, filters were washed to 0.2 SSC plus $-0.1 \%$ SDS at $65^{\circ} \mathrm{C}$ for 30 minutes and exposed at $-70^{\circ} \mathrm{C}$ for up to 2 weeks.

\section{RESULTS}

Figure 1 shows the 2D gel autoradiograph from testes of day 14.5 fetuses. From all the spots detected and analyzed, we were unable to find any that were present consistently only in testis or ovary. However, nine spots differed quantitatively and significantly in testis versus ovary with fold changes of $2 \mathrm{X}$ or greater. These differences for the nine spots were all significant at the 95\% confidence level (two-tailed test) by both Student's $\mathbf{t}$ and $\log$ transformed Student's t tests (Table 1). In addition, the size, isoelectric point and fold change are shown in this table. Seven of the proteins are expressed in greater amounts in the testis, whereas two proteins are expressed at greater levels in the ovary. The fold changes ranged from -4.14 (greater in testes) to +2.25 (greater in ovary). In addition, there were ten other proteins that were significantly different between the two sexes but were not followed because the fold change was smaller (data not shown).

The nine proteins were studied at three other times during development on fetuses genotyped with pM720 (data not shown) to determine whether we could detect any developmental patterns in their expression. The results are shown in Table 2. Protein 2 increases in amount in male tissues from day 8.5 to day 14.5. At day 8.5 , the protein is expressed less conspicuously in these total embryos, but it may be expressed more strongly in some parts of the male embryo and its concentration would be diluted. Its concentration increases in a gradual pattern in older fetuses as development of the gonads continues. For protein 5101, the male tissues
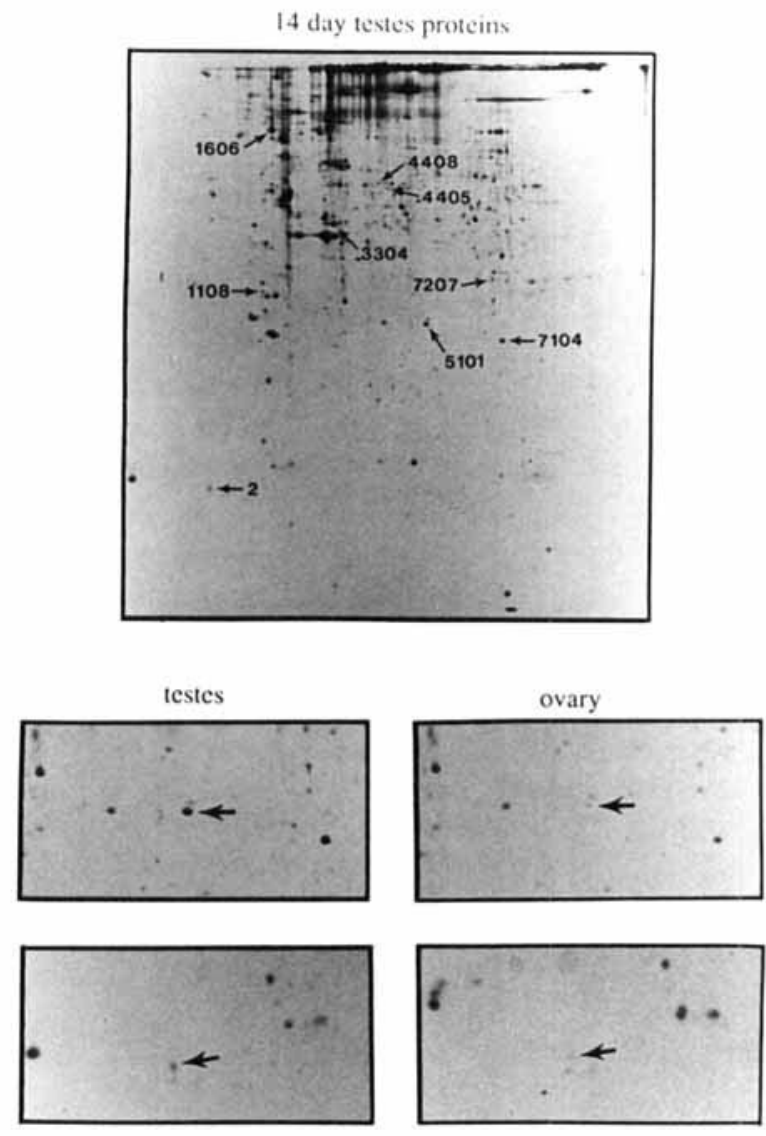

Fig. 1. Fluorogram of ${ }^{35} \mathrm{~S}$-labeled proteins separated by 2D gel electrophoresis from gonadal ridges. Top: complete gel from male gonad with proteins showing quantitative differences indicated. Bottom: magnified view of spots 2 and 5101, left in testes and right in ovary.

have a greater amount at each stage of development progressively. This is especially marked at day 14.5 . Proteins 1108, 1606, 4405, 4408, and 7104 showed no consistent pattern through development. Protein 3304 could not be identified positively in the day 10.5 and day 12.5 gels but at days 8.5 and 14.5 was greater in male than in female tissues, especially at day 8.5. Protein 7207 likewise could not be identified at day 10.5 and 12.5 but was greater in male tissues at days 8.5 and 14.5 , especially at day 14.5 .

\section{DISCUSSION}

Using 2D gel electrophoresis, we investigated protein differences in mouse testis and ovary during fetal development at about the time of gonadal differentiation. In mice, the gonads are morphologically indistinguishable until approximately day 13-14 post-fertilization (Whitten et al., 1979). For this reason, we chose day 14.5 for our initial studies. Since we found nine proteins that were expressed at greater levels in testes or ovary at this developmental state, we extended the study to include earlier stages of development. 
TABLE 1. Significant Proteins Detected in 14.5-Day Fetal Testes or Ovary of the C57BL/6J Strain of Mice

\begin{tabular}{rrrrc}
\hline Spot number & $\begin{array}{c}\text { Average p.p.m. } \\
\text { in testis }\end{array}$ & $\mathrm{M}_{\mathrm{r}}(\mathrm{kD})$ & $\mathrm{pI}$ & Fold change $^{\mathrm{a}}$ \\
\hline 2 & 111 & 16.8 & 4.59 & -2.59 \\
1108 & 111 & 34.2 & 5.05 & -3.22 \\
1606 & 1,323 & 100.0 & 5.13 & -2.37 \\
3304 & 860 & 44.7 & 5.50 & -2.37 \\
4405 & 95 & 55.4 & 6.00 & +2.00 \\
4408 & 95 & 58.4 & 5.91 & +2.25 \\
5101 & 239 & 30.5 & 6.36 & -4.14 \\
7104 & 368 & 28.7 & 7.10 & -1.91 \\
7207 & 406 & 35.8 & 6.97 & -1.97 \\
\hline
\end{tabular}

a Difference in testis vs. ovary (negative number indicates greater in testis).

TABLE 2. Differences in Expression of Proteins in Testis or Ovary During Fetal Development in Mice

\begin{tabular}{rcccc}
\hline & \multicolumn{4}{c}{ Fold change } \\
Spot number & $\begin{array}{c}8.5 \text { day } \\
\text { embryo }^{\mathrm{a}}\end{array}$ & $\begin{array}{c}10.5 \mathrm{day} \\
\text { trunk }^{\mathrm{a}}\end{array}$ & $\begin{array}{c}\text { 12.5 day } \\
\text { gonadal } \\
\text { ridges }^{\mathrm{a}}\end{array}$ & $\begin{array}{c}\text { 14.5 day } \\
\text { gonadal } \\
\text { ridges }\end{array}$ \\
\hline 2 & +1.55 & +1.09 & -1.46 & -2.59 \\
1108 & +3.50 & -2.10 & +1.36 & -3.22 \\
1606 & -1.68 & -1.78 & +3.45 & -2.37 \\
3304 & -4.14 & -1.32 & -1.63 & -2.37 \\
4405 & -1.50 & +3.56 & -1.91 & +2.00 \\
4408 & -1.01 & -1.84 & -1.11 & -4.14 \\
5101 & +1.20 & +1.81 & -1.22 & -1.91 \\
7104 & -1.38 & $\mathrm{~b}$ & $\mathrm{~b}$ & -1.97 \\
7207 & -1.54 & & & $\mathrm{~b}$
\end{tabular}

a Statistical analyses were not possible because only one embryo of each sex was studied at these earlier times.

${ }^{\mathrm{b}}$ Spot was either not detected or was ambiguous due to poor quality of $2 \mathrm{D}$ gel.

We found no proteins that were completely male or female specific. There are multiple possible reasons for this result. Only proteins containing methionine and at reasonable specific activity were detected. However, one can envision circumstances in which gonadal determination is not determined by the presence or absence of one or more proteins but is due to quantitative differences in these proteins. There could be a developmental cascade such that the important protein(s) increased in testes as they become more differentiated. Protein 2 or 5105 in our study could be such a protein. Such a protein could be functioning to increase testicular differentiation, as a positive regulator for other proteins involved in the process, or as a negative regulator for the process of ovarian differentiation. Other evidence in agreement with the notion that there is not a specific protein in mice which is responsible for testicular differentiation is the recent finding that the testis determining factor now has two candidate genes.

In contrast to our results, Muller and co-workers (1984) found a number of sex-specific proteins in rats during gonadal differentiation. Using $2 \mathrm{D}$ gel electrophoresis and silver staining, they found three sex specific proteins at the morphologically indifferent stage, and four additional sex-specific proteins at the onset of gonadal differentiation. These authors concluded that in the rat there is no period during development of the gonads at which these organs are indifferent biochemically as both testes and ovaries express specific proteins during their differentiation.

Protein 3304 or protein 7207 could be important proteins in gonadal differentiation but there were technical problems in detecting them at some stages. The $2 \mathrm{D}$ gels for 10.5 day trunks and 12.5 day gonadal ridges were of poorer quality than the 8.5 day fetal and 14.5 day gonadal ridge gels. Therefore, although the spots may have been there, they could not be identified with enough certainty to include those days in the analysis. These proteins could be identified readily in the gels from days 8.5 and 14.5 and followed a pattern consistent with a role in gonadal differentiation.

One could argue that our not finding any sex-specific proteins at the times of development we examined resulted from choosing improper times. Erickson and Verga (1989) reviewed evidence for expression of $\mathrm{Y}$ chromosomal genes earlier in development than gonadal differentiation. Epstein and co-workers (1980) 
reported that $\mathrm{Y}$-bearing preimplantation embryos were killed by treatment with antisera to serological $\mathrm{H}-\mathrm{Y}$ antigen. A Y chromosomal-encoded growth factor was reported by Tsunoda et al. (1985) to be expressed early in development. Finally $\mathrm{O}$ and co-workers reported evidence of sexual dimorphism in the wallaby before evidence of gonadal differentiation is seen (1988). Therefore the sex-specific quantitative differences in proteins which we found could have no relation to gonadal differentiation but may be involved in some other process such as germ cell maturation.

In conclusion, although we failed to find any proteins that were either testis or ovary specific at about the time of gonadal differentiation in mice, we found several proteins that differed significantly between the two sexes. Although we have not proved that these proteins are involved in gonadal development, the expression of these proteins in the pattern we observed suggests that the development of the gonads may involve quantitative differences. The recent discovery of a second candidate sex determining gene agrees with the hypothesis that several proteins are required for mammalian sex determination.

\section{ACKNOWLEDGMENTS}

This grant was supported by grant HD20670 to R.P.E. and HL 37703 to D.M.K. M.L.V. and D.M.K. are supported by the Howard Hughes Medical Institute. We thank Ms. Judy Worley for secretarial assistance.

\section{REFERENCES}

Affara NA, Chambers D, O'Brien J, Habeebu SSM, Kalaitsidaki M, Bishop CE, Ferguson-Smith MA (1989): Evidence for distinguishable transcripts of the putative testis determining gene (ZFY) and mapping of homologous cDNA sequences to chromosomes $\mathrm{X}, \mathrm{Y}$ and 9. Nucleic Acids Res 17:2987-2999.

Burgoyne PS (1989): Thumbs down for zinc finger. Nature 342:860862.

Eicher EM, Washburn LL, Whitney III, JB, Morrow KE (1982): Mus poschiavinus $\mathrm{Y}$ chromosome in the C57BL6/J murine genome causes sex reversal. Science 217:535-537.

Epstein CJ, Smith S, Travis B (1980): Expression of H-Y antigen on preimplaniation mouse embryos. Gamete Res 12:301-304.

Erickson RP, Verga V (1989): Minireview: Is zinc-finger $Y$ the sex-determining gene? Am J Hum Genet 45:671-674.

Feinberg AP, Vogelstein B (1984): A technique for radiolabelling DNA restriction endonuclease fragments to high specific activity. Addendum. Anal Biochem 137:266-267.

Garrels JI (1979): Two-dimensional gel electrophoresis and computer analysis of proteins synthesized by clonal cell lines. J Biol Chem 254:7961-7977.

Garrels JI, Farrar JT, Burwell CB (1989): The QUEST system for computer-analyzed two-dimensional electrophoresis of proteins. In Alis JE and Bravo R (eds): "Two-Dimensional Gel Electrophoresis of Proteins." New York: Academic Press, pp 37-91.

Gubbay J, Collignon J, Koopman P, Capel B, Economou A, Minsterberg A, Vivian N, Goodfellow P, Lovell-Badge R (1990): A gene mapping to the sex-determining region of the mouse $Y$ chromosome is a member of a novel family of embryonically expressed genes. Nature 346:245-250.

Kallikin LM, Fujimoto H, Witt MP, Verga V, Erickson RP (1989): A genomic clone of $Z f y-1$ from a $Y^{D O M}$ mouse strain detects postmeiotic gene expression of $Z f y$ in testes. Biochem Biophys Res Comm 165:1286-1291.

Koopman P, Gubbay J, Collignou J, Lovell-Badge R (1989): Zfy gene expression patterns are not compatible with a primary role in mouse sex determination. Nature 342:940-942.

Maniatis T, Fritsch EF, Sambrook J (1982): Molecular cloning: A laboratory manual. Cold Spring Harbor, NY: Cold Spring Harbor Laboratory.

Mardon G, Mosher R, Disteche CM, Nishioka Y, McLaren A, Page DC (1989): Duplication, deletion and polymorphism in the sex-determining region of the mouse $Y$ chromosome. Science 243:78-80.

Mardon G, Page DC (1989): The sex-determining region of the mouse Y chromosome encodes a protein with a highly acidic domain and 13 zinc fingers. Cell 56:765-770.

Muller U, Schindler H, Schempp W, Schott K, Neuhoff V (1984): Gene expression during gonadal differentiation in the rat: A two-dimensional gel electrophoresis investigation. Dev Genet 5:27-42.

O W-S, Short RV, Renfree MB, Shaw J (1988): Primary genetic control of somatic sexual differentiation in a mammal. Nature 331:736737.

Page DC, Mosher R, Simpson EM, Fisher EMC, Mardon G, Pollack J, McGilliway B, et al. (1987): The sex-determining region of the human Y chromosome encodes a finger protein. Cell 51:1091-1104.

Palmer MS, Sinclair AH, Berta P, Ellis NA, Goodfellow PN, Abbas NE, Fellous M (1989): Genetic evidence that $Z F Y$ is not the testis-determining factor. Nature 342:937-939.

Phillips SJ, Birkenmeier EH, Callahan R, Eicher EM (1982): Male and female mouse DNAs can be discriminated using retroviral probes. Nature 297:241-243.

Sinclair AH, Poster JW, Spencer JA, Page DC, Palmer M, Goodfellow PN, Marshall-Graves JA (1988): Sequences homologous to ZFY, a candidate human sex-determining gene, are autosomal in marsupials. Nature 336:780-783.

Sinclair AH, Berta P, Palmer MS, Hawkins JR, Griffiths BL, Smith MJ, Foster JW, Frischauf A-M, Lovell-Badge R, Goodfellow PN (1990): A gene from the human sex-determining region encodes a protein with homology to a conserved DNA-binding motif. Nature 346:241-244.

Tsunoda Y, Tokynaga T, Sukie T (1985): Altered sex ratio of live young after transfer of fast- and slow-developing mouse embryos. Gamete Res 12:301-304.

Whitten WK, Beamer WG, Byskov AG (1979): The morphology of fetal gonads of spontaneous mouse hermaphrodites. J Embryol Exp Morphol 52:63-78. 